\title{
A CASE OF PNEUMATOSIS CYSTOIDES INTESTINALIS ASSOCIATED WITH PEPTIC ULCER
}

\author{
Kamal Mansour, M.B., B.Chir. (Cairo) \\ Baptist Hospital, Gaza, via Egypt
}

Pneumatosis (or gas cysts) of the intestines is a rare disease that was first described in man by Bang in 1876 . It has been identified more frequently in animals, particularly swine fed on dairy refuse. It is characterized by the presence of cysts in the submucosal or subserosal layers, usually of the lower ileum, rarely of the duodenum, rectum or appendix. These cysts are tiny collections of gas enclosed within a wall of connective tissue supporting an inner layer of endothelium. The gas contained within the cysts is odourless, non-inflammable and is composed principally of nitrogen (up to $90 \%$ ), with smaller proportions of oxygen and carbon dioxide; on occasions other gases such as hydrogen and methane have been found.

Males are three times more commonly affected than females and the condition is commonest in the fourth and fifth decades - the decades of peptic ulcer. MacKenzie (195I) reported 12 cases in infants, as well as finding over 30 cases in the literature occurring in childhood.

It is difficult to attribute a definite clinical picture to the presence of multiple gas cysts in the walls of the intestines; usually symptoms occur because of some associated gastro-intestinal disease, the most common reported one being a stenosing ulcer of the pylorus and also intestinal tuberculous ulceration and gastric carcinoma. Symptoms may also occur from complications of the disease. Intestinal obstruction following blockage of the lumen by a mass of cysts, volvulus and intussusception has been recorded. Radiologically, gas may be seen under the diaphragm owing to spontaneous rupture of a cyst. Pneumatosis cystoides intestinalis is the only known condition which can explain a 'prolonged' or ' recurrent' pneumoperitoneum.

Hahn (1899) first reported the condition in a living subject and since then despite its early recognition, Schorr, Ullmann and Laufer (195I) and Koss (1952) have extensively reviewed the literature and have only found about 250 cases.
In 1949, Gazin, Brooke, Lerner and Prige reported the first pre-operative radiological diagnosis and more recently cases involving the sigmoid colon have been reported by Mattheys (1954), McGee, Penny and Williamson (1956). and Griffiths (1955). Two further cases of intestinal pneumatosis both involving the sigmoid colon were described by Shoesmith and Croge (I959).

The ætiology is puzzling; several ingeniofs theories have been advanced. It has been sug gested that the gas is a product of aerogenic organisms, but this is not supported by bacteri logical evidence. Many authors have suggested that the origin of the cysts is mechanical, and thes? gas of intestinal origin is forced through migute fissures in the mucous membrane as a result of vomiting, or irregular peristaltic action, be tht against this view is the absence of intestinal floga within the cysts. Nevertheless the commony accepted theory is that of Masson (1925), wis studied the condition in swine. He believed th the cysts were due to dilatation of lymphatic chyliferous channels, and that the gas is derived from chyle by chemical interaction with acte products of intestinal fermentation.

\section{Case History}

G.A., male, aged 50, admitted to Southern Bapt Hospital, Ajloun, Jordan, on October 16, 1959, con\&plaining of intermittent abdominal pain as well 25 chronic constipation for the past two to three years. Used to taking purgatives every two weeks. Toes purgative on day before admission which was followed by poor result and accompanied by distension an colicky pain. On day of admission he had repeated colics and the passage of only few cc.s of faeces. N

On Examination. Abdomen: markedly distended tympanitic note with few high-pitched bowel sounds Mild tenderness all over, but no rigidity. Rectats negative. Lungs: normal. Heart: regular, pulge 8o/min. Temp.: $36.9^{\circ} \mathrm{C}$. $\left(98.4^{\circ} \mathrm{F}\right.$.).

Investigation. $\mathrm{Hb}$. $11.5 \mathrm{gm} . / 100 \mathrm{ml}$. Total white coun 9,400. Differential count: non-segmented neutip $69 \%$ : segmented neutr., $15 \%$; lymphocytes, $16 \%$ ESR: I 1/23 mm., Westergren. Urine analysis, negatire 


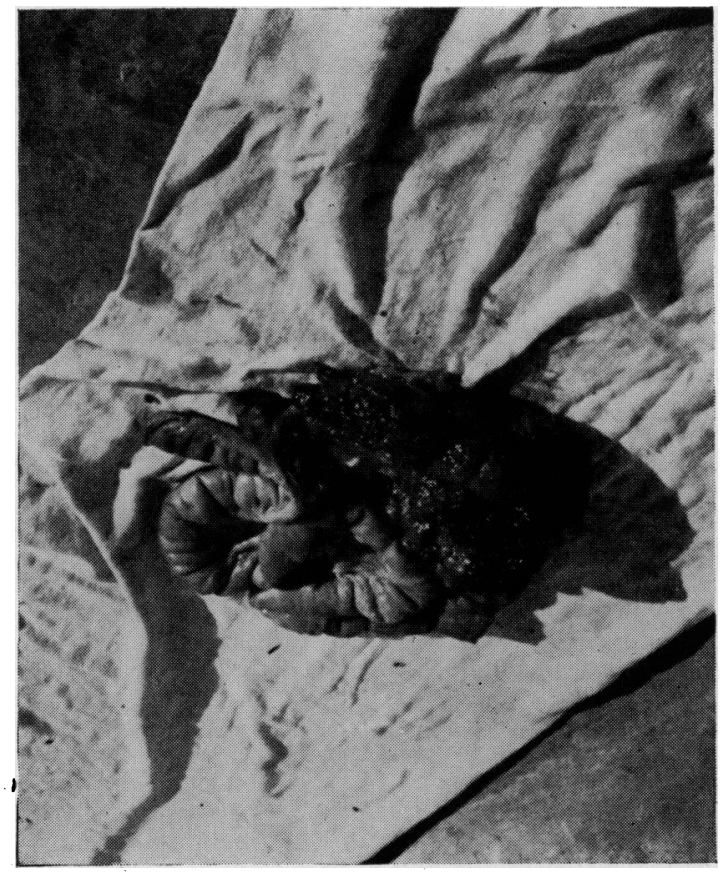

stools for occult blood, positive. Straight X-Ray of the abdomen showed multiple fluid levels.

A tentative diagnosis of intestinal obstruction was made. To elicit a diagnosis a laparotomy under ether anzesthesia was performed.

Operation. Right paramedian incision; free fluid was found in the peritoneal cavity, straw-coloured and not offensive. A sealed-off perforation in the pyloric region of the stomach was found with adhesions to the transverse colon and the gallbladder. Adhesions freed. The whole ileum was found to be studded with vesicles full of air with a big mass of the same invading and infiltrating a loop of small intestine about 3 in. from the ileo-creal junction. Some gangrenous areas were noticed in this mass. The whole mass with healthy bowel on both sides was resected with end-to-end $\overline{0}$ anastomosis. Four mattress sutures of catgut $00 \Omega$ chromic over an omental patch were applied to cover the perforation in the pylorus. Penicillin + streptomycin solution was put in the peritoneum. Abdomen was closed without drainage.

Convalescence was uneventful and the patient was discharged 12 days later, free from symptoms with normal bowel actions.

Histology. Sections revealed large cyst-like structures, lined by flattened cells with a chronic inflammatory process around, which is composed of lipid-laden macrophages, lymphocytes and a few giant cells, together with proliferating blood vessels lined by some endothelial cells in the neighbourhood.

\section{REFERENCES}

BANG, B. L. F. (1876) : Luftholdige Kyster i väggen af ileum og i nydannet bindeväu på sammes serosa, Nord. mëd. Ark., 8,-I.

Gazin, A. I., Brooke, W. S., Lerner, H. H., and Price, P. B. (1949): Pneumatosis Intestinalis; Roentgen Diagnosís and Surgical Management, Amer. F. Surg., 77, 563.

Griffiths, G. J. (1955): Pneumatosis Cystoides Intestinalis, Lancet, ii, 905.

HahN, E. (1899) : Uber Pneumatosis cystoides intestinorum hominis und einen duech Laparotomie behandelten Fall, Disch. med. Wschr., 25, 657.

Koss, L. G. (1952): Abdominal Gas Cysts (Pneumatosis Cystoides Intestinorum Hominis); Analysis with Report of Case and Critical Review of Literature, Arch. Path. Lab. Med., 53, 523.

McGre, A. R., Penny, S. F., and Williamson, N. L. (1956): Pneumatosis Cystoides Intestinalis, with Case Report, Radiology, 66, 88.

MacKenzie, E. P. (1951): Pneumatosis Intestinalis; Review of Literature with Report of 13 Cases, Pediatrics, 7, 537

Masson, P. (1925): Ann. Anat. path. med. chir., 2, 541 .

Mitriews, F. J. C. (1954): Enteric Pneumatosis, Brit. med. F., i, 851 .

Schorr, S., Ullmann, T. D., and Laufer, S. (195. I): Pneumatosis Cystoides Intestinalis, A.M.A. Arch. intern. Med. 88,362 .

Shorsmith, J. H., and Crone, W. P. (1959): Pneumatosis Cystoides Intestinalis, Brit. F. Surg., 46, 601. 